\title{
Concrete Behaviour with Volcanic Tuff Inclusion
}

\author{
Walid. Fouad Edris ${ }^{1,2}$, Safwat. Abdelkader ${ }^{2}$, Ahmed. H. E. Salama ${ }^{1,3, *}$, Abd Al-Kader A. Al Sayed ${ }^{4}$ \\ ${ }^{1}$ Department of Civil Engineering, Hijjawi Faculty for Engineering Technology, Yarmouk University. P.O. Box 566, Irbid 21163, \\ Jordan \\ ${ }^{2}$ Department of Civil Engineering, Giza High Institute of Engineering and Technology, Giza, Egypt \\ ${ }^{3}$ Department of Civil Engineering, Al-Azhar University, Nasr City 11884, Cairo, Egypt \\ ${ }^{4}$ Department of Civil Engineering, Higher Technological Institute, $10^{\text {th }}$ of Ramadan City, Egypt
}

Received May 20, 2021; Revised June 21, 2021; Accepted July 25, 2021

\section{Cite This Paper in the following Citation Styles}

(a): [1] Walid. Fouad Edris, Safwat. Abdelkader, Ahmed. H. E. Salama, Abd Al-Kader A. Al Sayed, "Concrete Behaviour with Volcanic Tuff Inclusion," Civil Engineering and Architecture, Vol. 9, No. 5, pp. 1434 - 1441, 2021. DOI: 10.13189/cea.2021.090516.

(b): Walid. Fouad Edris, Safwat. Abdelkader, Ahmed. H. E. Salama, Abd Al-Kader A. Al Sayed (2021). Concrete Behaviour with Volcanic Tuff Inclusion. Civil Engineering and Architecture, 9(5), 1434 - 1441. DOI: 10.13189/cea.2021.090516.

Copyright $\odot 2021$ by authors, all rights reserved. Authors agree that this article remains permanently open access under the terms of the Creative Commons Attribution License 4.0 International License

\begin{abstract}
This study evaluates the effect of substituting cement by volcanic tuff on the workability, mechanical properties, and durability of concrete. Five mixtures were prepared with volcanic tuff ratios to cement of $0 \%, 5 \%, 10 \%, 15 \%$ and $20 \%$. First, X-Ray Fluorescence (XRF) test for volcanic tuff was performed. Then, slump test was conducted for fresh concrete specimens. Moreover, tests for flexural strength, splitting tensile strength, elevated heat resistance, ultrasonic pulse velocity, and Scanning Electron Microscope (SEM) were performed at 28-days age of concrete specimens. Compressive strength, and absorption tests were conducted at 28, and 56-days ages of specimens. The study showed that slump, compressive strength, flexural strength, and splitting tensile strength were decreased with the increasing of volcanic tuff to cement replacement ratio at 28-days age. Additionally, the highest compressive strength and lowest water absorption for concrete were obtained at 56-days age of specimens and $10 \%$ volcanic tuff to cement replacement ratio.
\end{abstract}

Keywords Volcanic Tuff, Compressive Strength, Natural Pozzolan, Concrete, Cementitious Material

\section{Introduction}

Currently, the use of cement in concrete has negative environmental impacts due to the large number of carbon dioxide emissions during its manufacturing process. Meanwhile, cement is considered the most expensive ingredient in concrete because it consumes a large amount of energy during production which affecting the economic aspect of the concrete industry. Accordingly, it was necessary to search for materials that can be used as a supplementary of cement. These supplementary cementitious materials should be available, inexpensive, and can improve the properties of concrete. Different substitution materials will have different effects on the properties of the cement due to their chemical, physical and mineralogical characteristics [1-3].

Pozzolanic materials are widely used as supplementary cementitious materials in concrete. Pozzolanic materials can be classified to natural and artificial pozzolanic materials. Natural pozzolanic materials are materials such as zeolite, and volcanic tuff, while artificial pozzolanic materials are materials such as silica fume, fly ash, and metakaolin [4-6]. Volcanic tuff is one of the most pozzolanic materials which can be found as a natural material in Middle East countries (such as Egypt, Jordan, and Saudi Arabia). Jordan has available huge quantities of volcanic tuff (estimated as 800 million tons) [7]. Consequently, volcanic tuff was chosen to be used as a supplementary cementitious material in this research.

The replacement of cement by pozzolanic materials could improve the mechanical properties of cement and concrete composites. Replacement dosages between 5 to $50 \%$ by weight of cement were commonly used [8-10]. 
The popular ratio of cement replacing with the natural pozzolans was 15 to $20 \%$ [2]. Experimental research was studied on $0,10,30$, and $50 \%$ of Portland cement weight replacement by analcime, and clinoptilolite contents. The authors demonstrated that the highest strengths were obtained from samples containing $10 \%$ of both analcime and clinoptilolite blended cement contents [11]. Metakaolin has been used as a partial substitution for cement in the range of $4 \%$ to $28 \%$ by weight of cement. The highest compressive strength achieved at $16 \%$ metakaolin to cement substitution ratio [12]. Previous studies showed that volcanic tuff which contains a large proportion of $\mathrm{SiO}_{2}$ and $\mathrm{Al}_{2} \mathrm{O}_{3}$ improved the structural composition of cement mortar and concrete by forming additional C-S-H compound [10,13-15]. Other research illustrated that formation of C-S-H in hardened cement pastes enhanced the development of strength $[8,16-19]$.

In this research, volcanic tuff (natural Pozzolans) was investigated as a partial alternative material for cement in concrete. First, volcanic tuff was collected from mines located in the north of Jordan. Then, tests were carried out on concrete containing cementitious materials of volcanic tuff with $0,5,10,15$, and $20 \%$ cement replacement ratios. Fresh and hardened concrete properties were examined. The paper proceeds as follows, the experiments for concrete are illustrated. Then, results and discussion in addition to the conclusion are introduced at the end of paper.

\section{Materials and Methods}

\subsection{Materials}

Cement used in this study was Portland Pozzolan cement; Type II / P-P 42.5 N (JS 30-102007). The specific gravity was $3.15 \mathrm{~g} / \mathrm{cm}^{3}$, and the specific surface area was $4000 \mathrm{~cm}^{2} / \mathrm{g}$. Volcanic tuff used in the research was collected from mines located in north of Jordan. Chemical compositions of cement and volcanic tuff are presented in Table 1.

Table 1. Chemical Composition of Cement and Volcanic Tuff

\begin{tabular}{|c|c|c|}
\hline Oxides $(\%)$ & CEM II/P-P 42.5 N & Volcanic tuff \\
\hline $\mathrm{SiO}_{2}$ & 19.07 & 34.39 \\
\hline $\mathrm{Al}_{2} \mathrm{O}_{3}$ & 2.39 & 4.59 \\
\hline $\mathrm{Fe}_{2} \mathrm{O}_{3}$ & 9.52 & 31.46 \\
\hline $\mathrm{CaO}$ & 63.24 & 24.11 \\
\hline $\mathrm{MgO}$ & ----- & 0.49 \\
\hline $\mathrm{Na}_{2} \mathrm{O}$ & 0.014 & ----- \\
\hline $\mathrm{K}_{2} \mathrm{O}$ & 0.18 & 1.3 \\
\hline $\mathrm{SO}_{3}$ & 2.47 & ---- \\
\hline
\end{tabular}

Chemical compositions of volcanic tuff showed that total content of $\mathrm{SiO}_{2}, \mathrm{Al}_{2} \mathrm{O}_{3}$, and $\mathrm{Fe}_{2} \mathrm{O}_{3}$ was found to be approximately $71 \%$. This ratio is little more than the minimum requirement (70\%) specified in ASTM C-618 for natural pozzolans. Volcanic tuff was grinded in Los Angeles machine then sieved through a sieve \#200. The maximum particle size of volcanic tuff, used in this paper, was less than $75 \mu \mathrm{m}$.

Fine and coarse aggregates used for casting concrete mixtures were obtained from Irbid area, Jordan. Physical properties of sand and conventional crushed limestone aggregate used are shown in Table 2. Fig. 1 shows the relation between sieve opening size and passing percentage of fine and coarse aggregates.

Table 2. Physical Properties of Fine and Coarse Aggregates

\begin{tabular}{|c|c|c|}
\hline Aggregate type & $\begin{array}{c}\text { Fine } \\
\text { Aggregate. }\end{array}$ & $\begin{array}{c}\text { Coarse } \\
\text { Aggregate. }\end{array}$ \\
\hline $\mathrm{D}_{\max }(\mathrm{mm})$ & ----- & 25 \\
\hline Specific Gravity (Dry) & 2.28 & 2.34 \\
\hline Specific Gravity (SSD) & 2.41 & 2.44 \\
\hline Bulk Density $\left(\mathrm{Kg} / \mathrm{m}^{3}\right)$ & ---- & 1521.8 \\
\hline Absorption $(\%)$ & 5.59 & 4.09 \\
\hline Fineness Modulus & 2.9 & ----- \\
\hline Moisture Content $(\%)$ & 3.73 & 2.02 \\
\hline
\end{tabular}

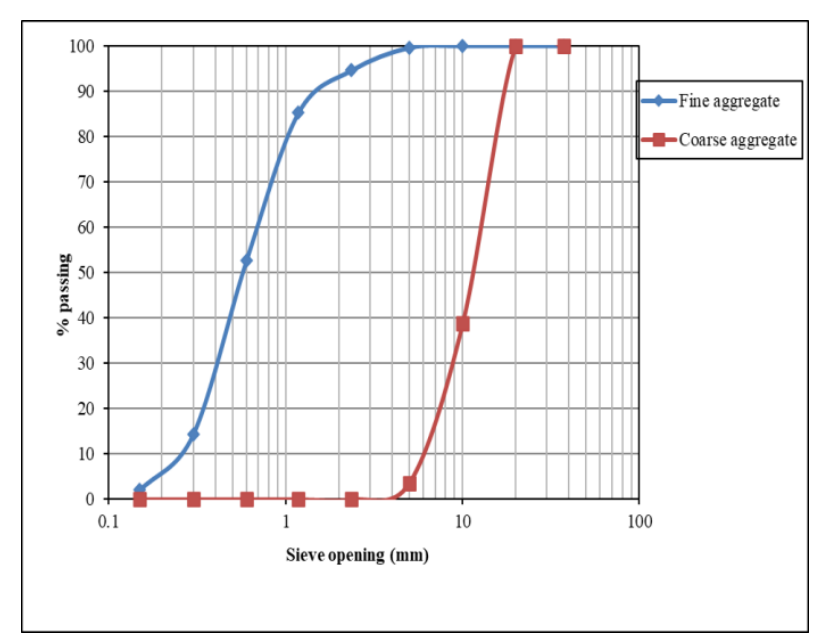

Figure 1. Relation Between Sieve Opening Size and Passing Percentage of Aggregate.

\subsection{Methods}

Five concrete mixtures, with $0,5,10,15$ and $20 \%$ of volcanic tuff cement replacement included, were used. All concrete mixtures were designed according to ACI C-211. A slump test of fresh concrete prepared with different percentages of volcanic tuff was performed according to ASTM C143.

A compressive test was performed to evaluate the strength development of $100 \times 100 \times 100 \mathrm{~mm}$ cubic specimens according to BS EN 12390-3:2009. Nine Cubic specimens were tested at 7, 28, and 56-days ages of curing (three cubes for each age) and the average compressive strengths were recorded. Compressive strength tests of all 
specimens were evaluated using a universal hydraulic testing machine (2000 KN capacity).

Four-point load flexural strength was tested for $150 \mathrm{x}$ $150 \times 750 \mathrm{~mm}$ concrete prisms according to ASTM C78 at 28 days age. A splitting tensile test was performed, according to ASTM C496, by universal hydraulic testing machine (2000 KN capacity). Six cylindrical specimens of $100 \times 200 \mathrm{~mm}$ were tested at 7 and 28-days ages (three cylinders for each age). Tensile strength was calculated by dividing the maximum load (2P) sustained with geometrical factors $(\pi \mathrm{DL})$.

Water absorption was tested for concrete specimens per ASTM C-642. Three specimens were cut into slices with a maximum thickness of $50 \mathrm{~mm}$ and $100 \mathrm{~mm}$ diameter for each concrete mix and tested for 28, and 56-days ages. Water absorption values were obtained by drying the specimens until a constant mass was achieved, immersed them in water, and measured the increase in mass as a percentage of dry mass.

Elevated heat resistance test was performed according to [20]. Three cubic specimens, at 28 days age of curing, were placed in an electrical furnace and heated at a fixed heating rate of $10^{\circ} \mathrm{C} / \mathrm{min}$ to reach the elevated temperature of $250^{\circ} \mathrm{C}$ and then compression tests were performed. The electrically heated furnace used here was designed for a maximum temperature of $3000^{\circ} \mathrm{C}$.

An ultrasonic pulse velocity test was conducted on six cubic specimens at 28 and 56- days ages (three cubes for each age). The test equipment generates an amplified pulse and then transfers it through the concrete specimens. The transmission time for pulse that is taken through the concrete specimens was measured in microsecond $(\mu \mathrm{s})$.

The microstructure study was undertaken to observe the structure of volcanic tuff concrete, including the effect of different mix formulations on the microstructure, presence of pores, and micro-cracks. Scanning Electron Microscopy (SEM) was performed on crushed concrete samples tested at 28 days age. SEM imaging was conducted on an EMITECH K550X. Concrete specimens were prepared using the mix design presented in Table 3.

Table 3. Mix Proportions of Concrete Control Mix

\begin{tabular}{|c|c|c|c|c|c|}
\hline Designation & V0 & V5 & V10 & V15 & V20 \\
\hline Cement (gm) & 320 & 304 & 288 & 272 & 256 \\
\hline Fine aggregate $(\mathrm{gm})$ & \multicolumn{5}{|c|}{626.5} \\
\hline Coarse aggregate $(\mathrm{gm})$ & \multicolumn{5}{|c|}{1044} \\
\hline $\mathrm{W} / \mathrm{Cm}$ ratio & \multicolumn{5}{|c|}{0.61} \\
\hline Replacement ratio (\%) & 0 & 5 & 10 & 15 & 20 \\
\hline Volcanic tuff (gm) & 0 & 16 & 32 & 48 & 64 \\
\hline
\end{tabular}

\section{Results and Discussion}

\subsection{Workability}

For fresh concrete, a slump test was conducted for all mixes to study the effect of volcanic tuff as a cement replacement on the consistency of fresh concrete. Table 4 depicts that increasing replacement ratio of volcanic tuff decreased concrete workability by $8.3,41.7,66.7$, and $66.7 \%$ for $5,10,15$, and $20 \%$ replacement ratios, respectively. The cause, according to [21, 22], is that natural pozzolans (volcanic tuff) absorbs a high amount of mixture water due to their porous structure.

Table 4. Slump of Concrete Specimens Containing Volcanic Tuff

\begin{tabular}{|c|c|c|c|c|c|}
\hline $\begin{array}{c}\text { Percentage of } \\
\text { volcanic tuff (\%) }\end{array}$ & 0 & 5 & 10 & 15 & 20 \\
\hline slump (mm) & 120 & 110 & 70 & 40 & 40 \\
\hline
\end{tabular}

\subsection{Compressive Strength}

Figure 2 shows the results for compressive strength of control mix and mixes with different replacement ratios of volcanic tuff at 7, 28, and 56-days ages. Fig. 2 demonstrates that at early ages ( 7 and 28 days), the control mix has the highest compressive strength among different concrete mixes.

At 7 days age, compressive strength decreased by 11.26 , $20,45.8$, and $53.6 \%$ for $5,10,15$, and $20 \%$ replacement ratios, respectively. Whereas, at 28 days age of specimen, compressive strength decreased by $4.1,9.4,38.22$, and 47.8 for $5,10,15$, and $20 \%$ replacement ratios, respectively.

At 56 days age, compressive strength increased by 21.5 , and $25.7 \%$ for 5 , and $10 \%$ replacement ratios and decreased by 20.4 , and 28.9 for 15 , and $20 \%$ replacement ratios, respectively.

This mainly is due to the decreasing of cement amount in blended cement mixture and, consequently, decreasing the amount of calcium silicate hydrates, C-S-H, which is responsible for strength development at 7-, and 28-days age [23]. While, at later age (56 days), low replacement levels (5 and 10 wt.\%) of volcanic tuffs produced satisfactory compressive strengths. The increasing in compressive strength at later age (56 days), was observed when replacing cement by $10 \%$ of volcanic tuff due to the presence of a proportion of silicon oxide $\mathrm{SiO}_{2}$, which in turn interacts with the un-hydrated calcium hydroxide $\mathrm{Ca}(\mathrm{OH})_{2}$ and creates an additional bond of $(\mathrm{C}-\mathrm{S}-\mathrm{H})$. This reaction occurs slowly, so the compressive strength increases over time as shown in Fig. 2. 


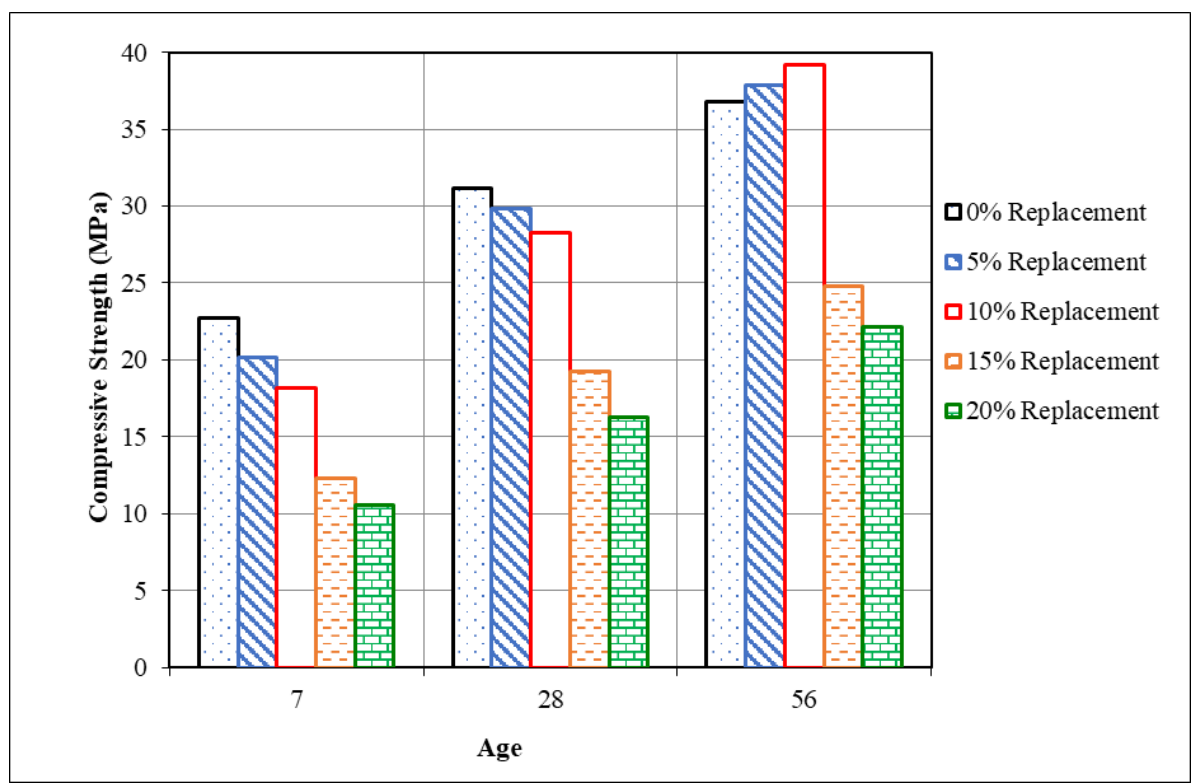

Figure 2. Compressive Strength of Concrete Cubes with Different Volcanic Tuff Ratios at 7, 28, and 56-Days Ages

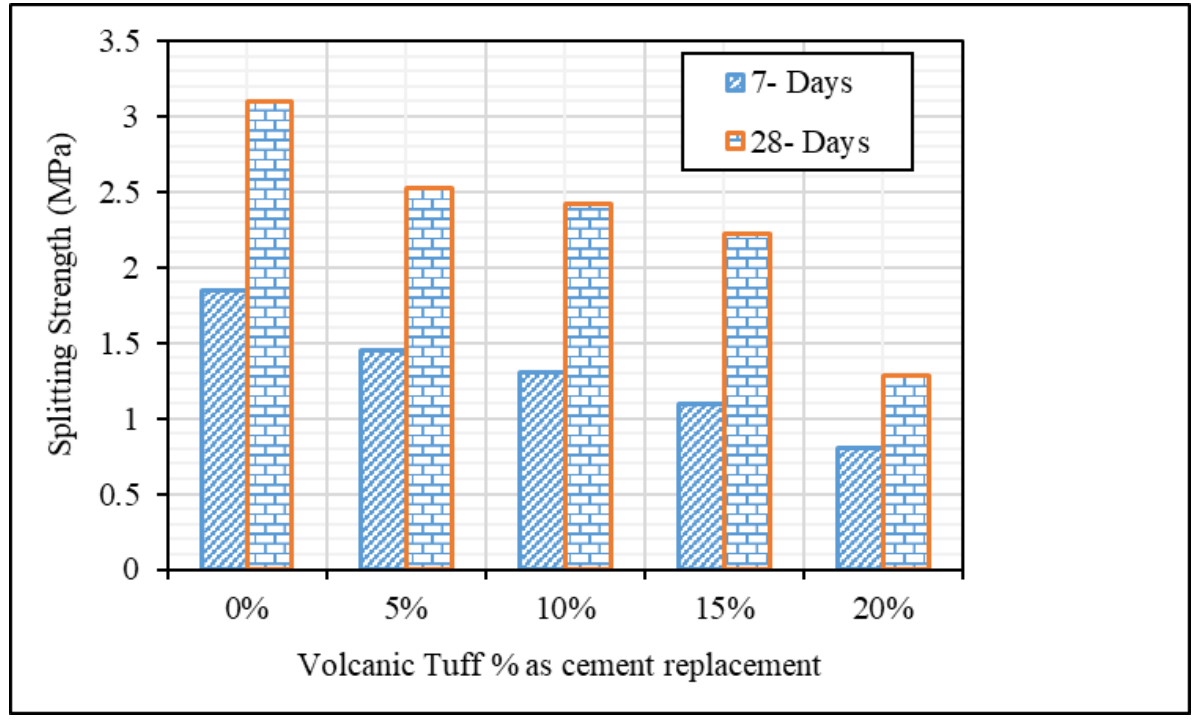

Figure 3. Splitting Tensile Strength of Concrete Cubes with Different Volcanic Tuff Ratios at 7, and 28-Days Ages

\subsection{Splitting and Flexural Strengths}

Splitting and flexural strengths of concrete for all partial replacement of cement by Volcanic Tuff at 7, and 28- days ages are plotted in Fig. 3 and Fig. 4. respectively. It can be seen from Fig. 3. that, with increasing of volcanic tuff by $5,10,15$, and $20 \%$ replacement ratios, the splitting tensile strength decreased by 21.6, 29.2, 40.5, and $56.8 \%$ at 7 days age, respectively. At 28 days age, the splitting tensile strength decreased by 18.4, 21.9, 28.4, and $58.7 \%$ for $5,10,15$, and $20 \%$ replacement ratios, respectively.

The effect of volcanic tuff with different replacement ratios on flexural strength at 28 days age is presented in Fig. 4. Replacement of cement by volcanic tuff has slightly reduced the flexural strength by $8.7,18.7,28.4$, and $58.7 \%$ for $5,10,15$, and $20 \%$ replacement ratios, respectively. This can be explained by the increasing of Volcanic Tuff amount that leads to reduce the cement amount and significant retard of hydration which consequently decrease the amount of $\mathrm{C}_{3} \mathrm{~S}$ and $\mathrm{C}_{2} \mathrm{~S}$. 


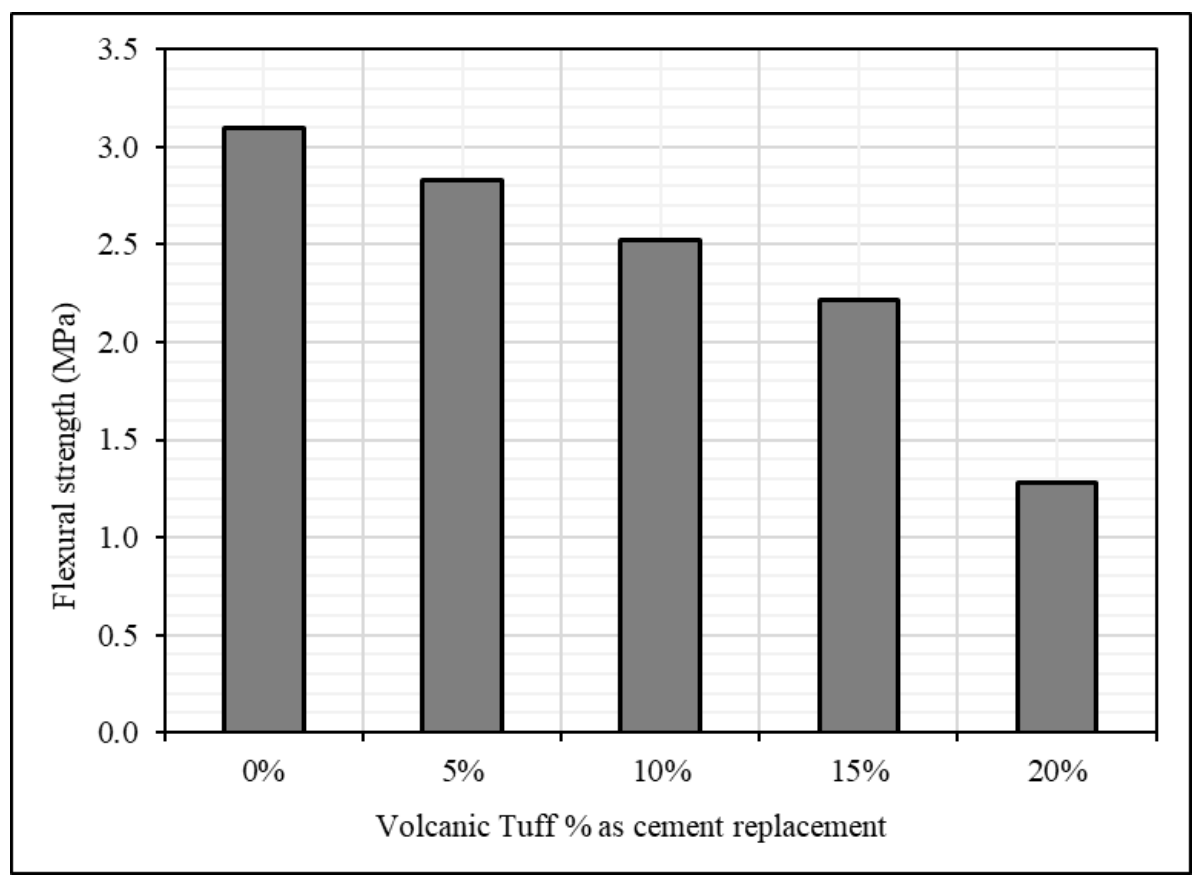

Figure 4. Flexural Strength of Concrete Prisms with Different Volcanic Tuff Ratios at the Age of 28 Days

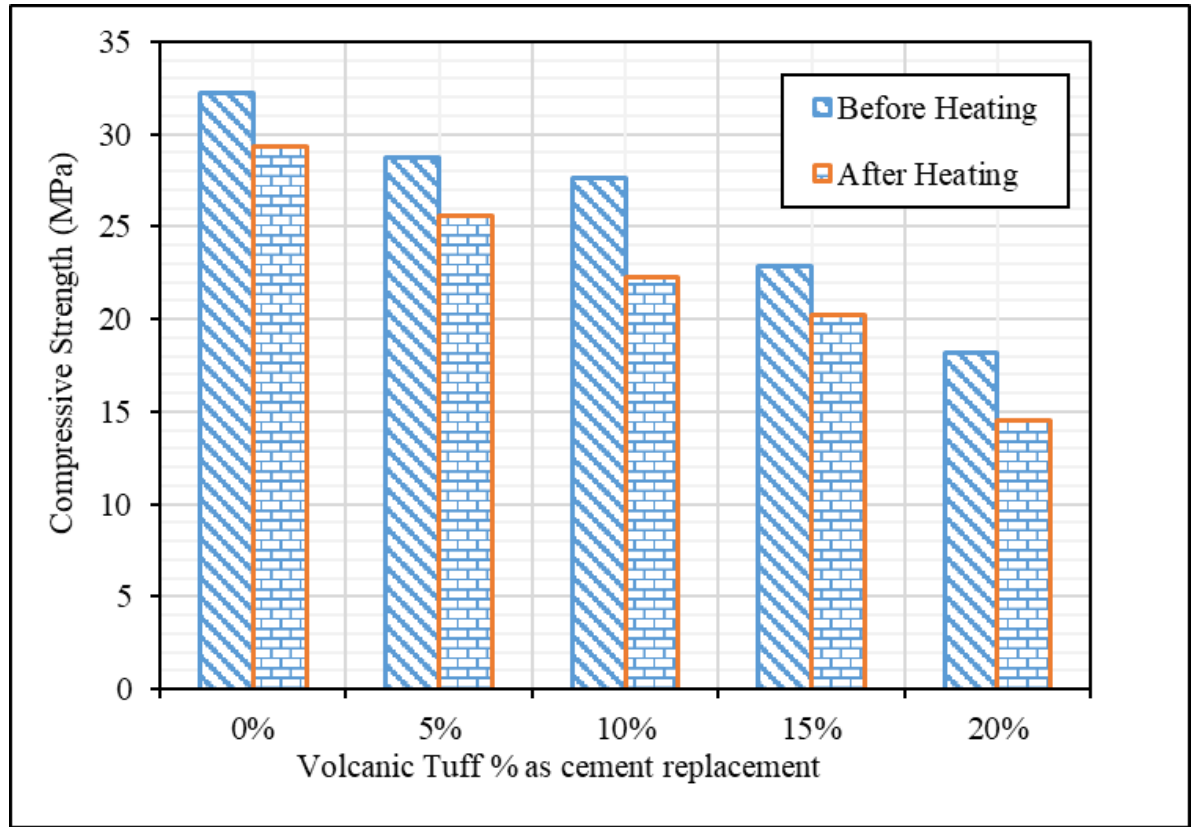

Figure 5. Compressive Strengths of Concrete Cubes with Different Volcanic Tuff Concentrations Before and After $250{ }^{\circ} \mathrm{C}$ Heated Temperature at 28 Days Age.

\subsection{Elevated Heat Resistance}

Fig. 5. shows the effect of elevated temperature on the compressive strength of concrete specimens with different levels of volcanic tuff. At 28 days age, compressive strength of control and partial cement replacement mixes with 5\%,10\%, 15\% and 20\% were decreased after heating. This result is mainly due to an elevated temperature, the deterioration of calcium hydroxide, dehydration of calcium silicate hydrates, and thermal expansion mismatch of aggregates and hydrated cement paste [24].

\subsection{Water Absorption}

Table 5 shows concrete specimen's percentages of water absorption determined at 28 , and 56- days ages. It can be noted that the replacement of cement by volcanic tuff has a slightly increasing effect on water absorption at 28 days age by $11.1,11.6,16.8$, and $19.9 \%$ for $5,10,15$, and $20 \%$ replacement ratios, respectively. At 56 days age, 
water absorption decreased by 1.9 , and $5 \%$ for 5 , and $10 \%$ replacement ratios and increased by 3.6 , and $11.3 \%$ for 15 , and $20 \%$ replacement ratios, respectively. These results can be attributed to voids increasing which cause reduction in durability.

Table 5. Percentage of Concrete Absorption at 28, and 56- Days Ages

\begin{tabular}{|c|c|c|}
\hline \multirow{2}{*}{$\begin{array}{c}\text { Volcanic Tuff } \\
(\%)\end{array}$} & 28-Days & 56-Days \\
\cline { 2 - 3 } & \multicolumn{2}{|c|}{ Absorption (\%) } \\
\hline 0 & 6.38 & 5.82 \\
\hline 5 & 7.09 & 5.71 \\
\hline 10 & 7.12 & 5.53 \\
\hline 15 & 7.45 & 6.03 \\
\hline 20 & 7.65 & 6.48 \\
\hline
\end{tabular}

\subsection{Ultrasonic Pulse Velocity}

Fig. 6. shows values of time ( $\mu \mathrm{s})$ determined for 28 , and 56- days ages versus volcanic tuff percentage as cement replacement. At 28 days, the time that a pulse should cross the $100 \times 100 \times 100 \mathrm{~mm}$ cube increased by $1.1,1.4,2.4$, and $2.9 \%$ for $5,10,15$, and $20 \%$ replacement ratios, respectively. Whereas, at 56 days age, pulse time decreased by 0.44 , and 0.88 for 5 , and $10 \%$ replacement ratios then increased by 1.3 , and 1.8 for 15 , and $20 \%$ replacement ratios, respectively.

The time that pulse takes through cube is an indication of the length that it took where it flows in the hardened concrete. So, as the time increase the voids increase. The trends shown in both absorption and ultrasonic pulse velocity can be explained by the low-rate pozzolanic reactions that produce $\mathrm{C}-\mathrm{S}-\mathrm{H}$, yielding a decrease in porosity and increase of strength [25].

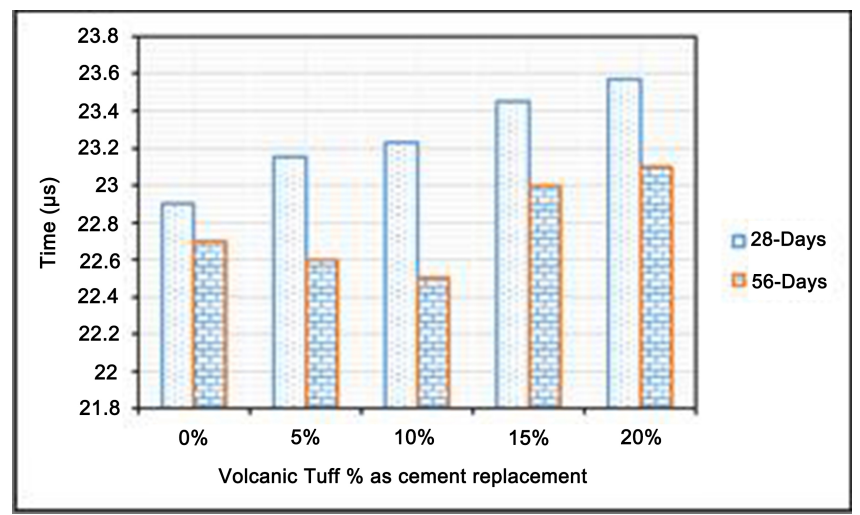

Figure 6. Ultrasonic Time of Concrete Cubes with Different Volcanic Tuff Concentrations at 28-, and 56-Days Ages

\subsection{Microstructure Analysis}

Fig. 7. shows the SEM analysis conducted for the control mix specimen and, the concrete with different ratios of volcanic tuff replacement at 28 days age.

Figs. 7a to $7 \mathrm{e}$ show that, the most distinct difference in the microstructure between the different percentages of volcanic tuff as cement replacement concrete mixtures with control mix. According to the comparison between Figs. 7b, 7c with Fig. 7a, the control mix appears to be less porous and denser compared with others, which would contribute to its higher mechanical and durability properties. Volcanic tuff increasing the number of pores in its concrete mixes.

Figs.7d and 7e show SEM images of the concrete specimen prepared with 15 , and $20 \%$ of the volcanic tuff, respectively. At 28 days age, compressive strengths obtained are lower than control mix. SEM image shows the presence of unreacted volcanic tuff particles. These observations could explain the reduction in compressive strength of these mixes with a relatively high replacement level of Portland cement with volcanic tuff. The main explanation of compressive strengths reduction with $15 \%$ and $20 \%$ volcanic tuff is due to diminish of cement quantity in this concrete. From Fig. 7, it can be concluded that there was a tendency for a decrease in the number of unreacted volcanic tuff particles, which may be according to the weakly pozzolanic activity of volcanic tuff.

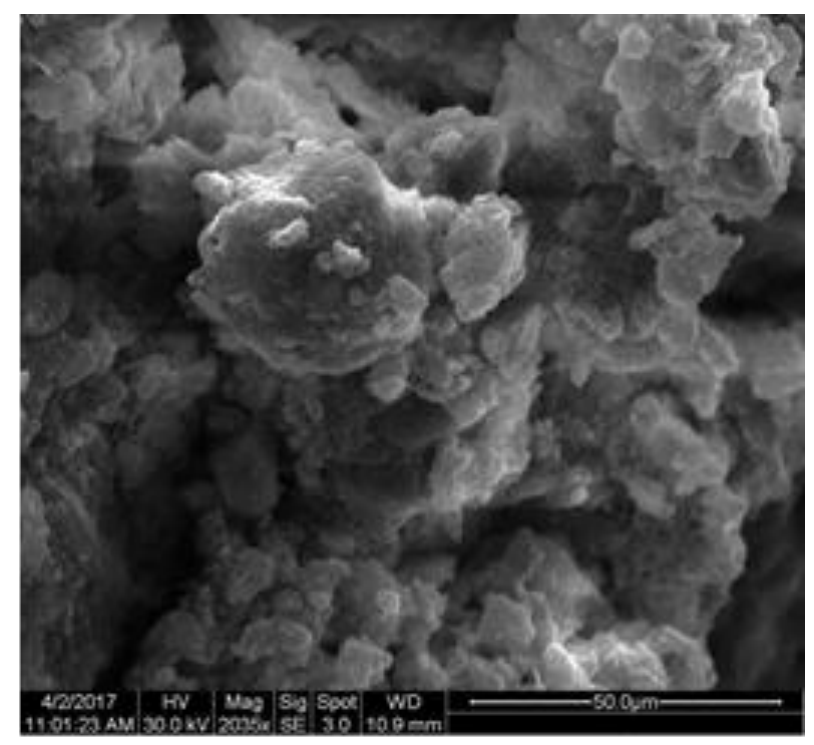

(a) 


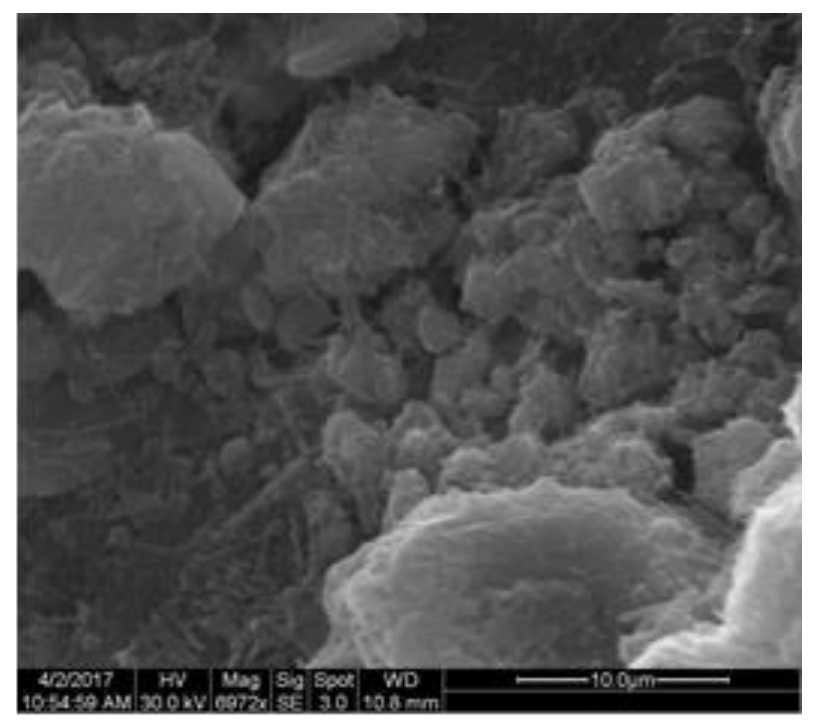

(b)

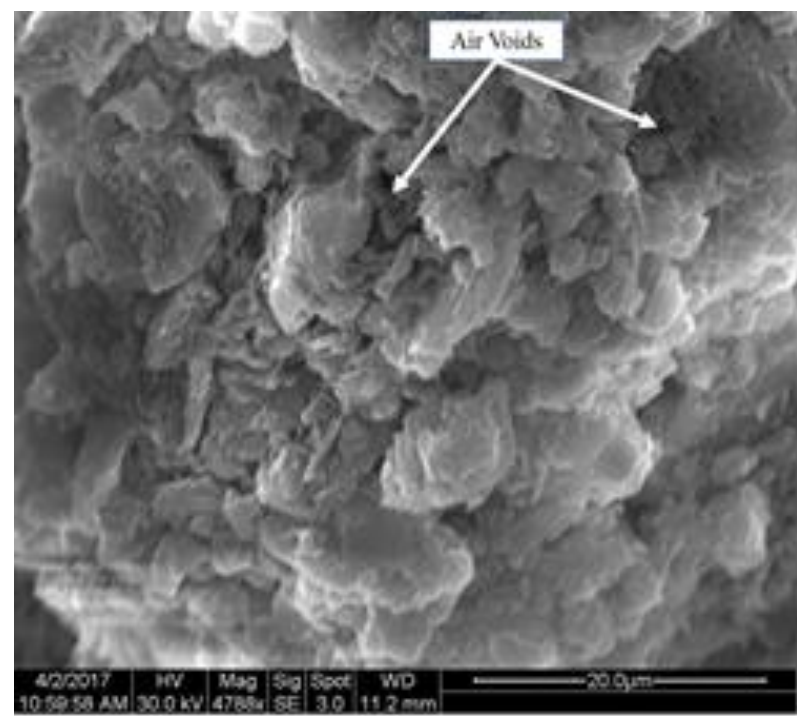

(c)

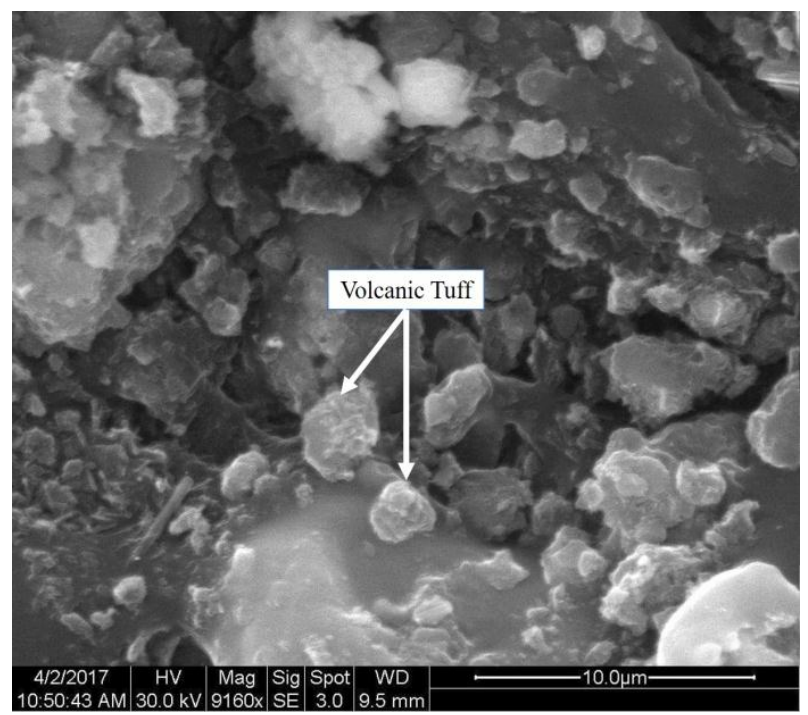

(d)

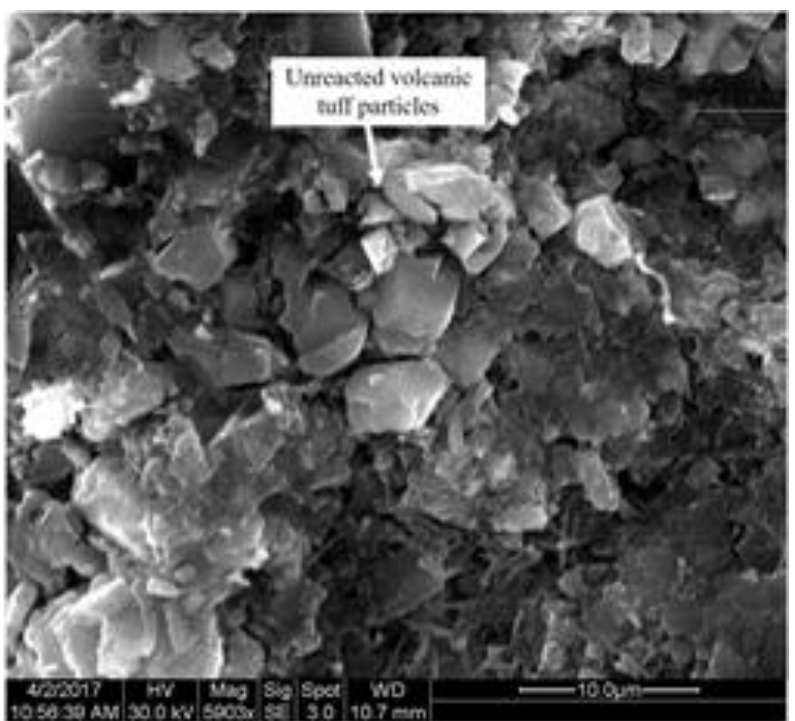

(e)

Figure 7. SEM Micrograph for: (A) Control Mix, (B) $5 \%$ Volcanic Tuff Cement Replacement, (C) 10\% Volcanic Tuff Cement Replacement, (D) 15\% Volcanic Tuff Cement Replacement, and (E) 20\% Volcanic Tuff

\section{Conclusions}

This study investigated the effect of substituting cement by $5,10,15$, and $20 \%$ of volcanic tuff on properties of concrete at 7-, 28-, and 56-days age. Based on the experimental results, the following conclusions could be drawn:

- According to fresh concrete properties, workability decreased from $8.3 \%$ to $66.7 \%$ with increasing of volcanic tuff replacement ratios.

- At 7 and 28- days ages, concrete mix without volcanic tuff replacement ratio had the highest value of compressive, and splitting tensile strengths by (22.7, 31.2 MPa), and (1.85, 3.1 MPa), respectively.

- At 28 days age, control concrete mix had the highest value of flexural strength by (3.1 MPa).

- At 56 days age, the higher compressive strength obtained at $10 \%$ of volcanic tuff cement replacement by $25.7 \%$ (39.2 MPa).

- Regarding the durability properties, at 28 days age, increase of volcanic tuff as cement replacement led to a slightly negative effect on water absorption percentage and ultrasonic pulse velocity compared with control mix (by $19.9 \%$ and $2.9 \%$, respectively).

- At 56 days age, the substitution of cement with $10 \%$ volcanic tuff, the water absorption percentage and ultrasonic pulse velocity were approximately appropriate (decreased by $5 \%$ and $0.88 \%$, respectively).

- At 28 days age, all microstructure images of mixes containing volcanic tuff with different replacement ratios showed more porous compared with control 
concrete mix, which directly affects the mechanical and durability properties.

\section{Acknowledgements}

The project presented in this article is supported by Giza High Institute of Engineering \& Technology and Yarmouk University.

\section{REFERENCES}

[1] I. Olgun, A. S. İ. M. Erdogan, Y. Sevinc, V. Kula. Effects of colemanite waste, cool bottom ash, and fly ash on the properties of cement. Cement and concrete research, 31, 3, 491- 494, 2001.

[2] K. Bougara, A. Kadri, A. Khelafi, H. Kadri, E. Ezziane. Compressive strength of mortar containing natural pozzolan under various curing temperatures. Cement and Concrete Composites, 29, 8,587-593, 2007.

[3] S. A. Ameri, F. Bahrami, N. Zareei. Microstructure, strength, and durability of eco-friendly concrete containing sugarcane bagasse ash. Construction and Building Materials,184, 258- 268, 2018.

[4] A. Malhotra, V. M. Bilodeau. High-volume fly ash system: concrete solution for sustainable development. Materials Journal, 97, 1, 41- 48, 2000.

[5] P. Rukzon, S. Chindaprasirt. Strength, porosity, and corrosion resistance of ternary blend Portland cement, rice husk ash and fly ash mortar. Construction and Building Materials, 22, 8,1601-1606, 2008.

[6] R. D. Hooton. Influence of silica fume replacement of cement on physical properties and resistance to sulfate attack, freezing and thawing, and alkali-silica reactivity. Materials Journal, 90, 2, 143- 151, 1993.

[7] H.N. Khoury, K.M. Ibrahim, R.A. Al Dwairi, D.G. Torrente. Widespread zeolitization of the NeogeneQuaternary volcanic tuff in Jordan, J. Afr. Earth. Sci. 101, 420- 429, 2015.

[8] B. Uçar, A. Öteyaka, B. Uz, V. Yılmaz. Properties of zeolitic tuff (clinoptilolite) blended Portland cement. Building and Environment, 42, 11, 3808-3815, 2007.

[9] F. Y1lmaz, K. Köse, M. M. Sümer, M. Yurdusev, M. A Canpolat. Use of zeolite, coal bottom ash, and fly ash as replacement materials in cement production. Cement and Concrete Research, 34, 5, 731-735, 2004.

[10] N. Feng, G. Li, X. Zang. High-strength and flowing concrete with a zeolitic mineral admixture. ASTM Cem Concr Aggr, 12, 2, 61- 9, 1990.

[11] Y. YAZICIOĞLU, Ö. F. AKGÜN. Experimental research on alternative pozzolan analcime to clinoptilolite.
Romanian Journal of Materials, 50, 4, 502- 509, 2020.

[12] Mayuri A. Chandak, P. Y. Pawade. Compressive Strength and Ultrasonic Pulse Velocity of Concrete with Metakaolin. Civil Engineering and Architecture, 8(6), 1277 -1282, 2020. DOI: $10.13189 /$ cea.2020.080611

[13] E. A. Cheeseman, C. Knight, J. Loizidou, M. Ortega. Properties of alkali-activated clinoptilolite. Cement and Concrete Research, 30, 10, 1641-1646, 2000.

[14] T. Kakali, G. Kontoleon, F. Perraki. The effect of natural zeolites on the early hydration of Portland cement. Microporous and mesoporous materials, 61, 1-3, 205-212, 2003.

[15] D. Liguori, B. Colella, C Caputo. Some advances in understanding the pozzolanic activity of zeolites. The effect of zeolite structure. Cement and Concrete Composites, 30, 5, 455- 462, 2008.

[16] X. Moreno, N. Umaña, J. T. Alastuey, A. Hernández, E. Lopez-Soler, A. Plana, F. Querol. Synthesis of zeolites from coal fly ash: an overview. International Journal of coal geology, 50, 1- 4, 413- 423, 2002.

[17] S. J. T. Montgomery, D. M. Sollars, C. J. Perry, R. Pollard. Organic compounds in the cement-based stabilization/solidification of hazardous mixed wastes-Mechanistic and process considerations. Journal of Hazardous Materials, 28, 3, 313-327, 1991.

[18] F. Massazza, Pozzolanic cements. Cement and Concrete composites, 15, 4, 185-214, 1993.

[19] G. Sasnauskas, V. Daukšys, M. Palubinskaite, D Skripkiūnas. Peculiarities of hydration of cement paste with the addition of hydrosulfite. Materials Science-Poland, 25, 3, 2007.

[20] O. A. Al Bakri, A. M. Kamarudin, H. Nizar, I. K Abdulkareem. Fire resistance evaluation of lightweight geopolymer concrete system exposed to elevated temperatures of 100-800 C. Trans Tech Publications Ltd, 594, 427-432, 2014.

[21] B. Uzal, L. Turanli. Studies on blended cement containing a high volume of natural pozzolans. Cement and concrete research, 33, 11, 1777-1781, 2003.

[22] D. Chaniotakis, E. Stamatakis, M. G. Fragoulis. Zeolitic tuffs of Kimolos Island, Aegean Sea, Greece, and their industrial potential. Cement and Concrete Research, 27, 6, 889- 905, 1997.

[23] S. Alkheder, Y.T. Obaidat, M. Taamneh. Effect of olive waste (Husk) on the behavior of cement paste. Case Studies in Construction Materials, 5, 19- 25, 2016.

[24] P. K. Patro, S. K. Acharya. Strength, sorption, and abrasion characteristics of concrete using ferrochrome ash (FCA) and lime as partial replacement of cement. Cement and Concrete Composites, 25-16,74,2016.

[25] A. Ababneh, F. Matalkah. Potential use of Jordanian volcanic tuffs as supplementary cementitious materials. case studies in construction materials, 8,193-202, 2018. 